\title{
Perencanaan Kebutuhan Base Station Jaringan Fixed WiMAX Berdasarkan Demand Site
}

\author{
Nurwahidah Jamal, ST. MT \\ Jurusan Teknik Elektronika \\ Politeknik Negeri Balikpapan \\ Jl. Soekarno Hatta KM.8 Balikpapan \\ idajama105@gmail.com
}

\begin{abstract}
This research is done to know the cell range and base station needs in specific area by using fixed WiMAX technology.

The planning is started with some of assumption as the initial data to do a calculation of growth and density of customer which is used to calculate the cell range and base station needs for voice services and data.

In this research, for 500.000 population in an area with $240 \mathrm{~km}^{2}$ has taken the base station needs as 148 cell for the urban area with range of each cell is $0,98 \mathrm{~km}^{2}$ and 63 cell for sub-urban area with the cell range of each cell is $1,53 \mathrm{~km}^{2}$.
\end{abstract}

Keywords : Fixed WiMAX, Demand Site, Urban, Sub-urban, Base Station.

\begin{abstract}
Abstrak
Penelitian ini dilakukan untuk mengetahui luas sel dan kebutuhan base station pada suatu wilayah tertentu dengan menggunakan teknologi fixed WiMAX.

Perencanaan diawali dengan beberapa asumsi-asumsi sebagai data awal untuk melakukan perhitungan pertumbuhan dan kepadatan pelanggan yang selanjutnya digunakan untuk menghitung luas sel dan kebutuhan base station untuk layanan voice dan data.

Pada penelitian ini untuk total populasi 500.000 jiwa pada suatu wilayah seluas $240 \mathrm{~km}^{2}$ diperoleh kebutuhan base station sebanyak 148 sel untuk wilayah urban dengan luas masing-masing sel adalah $0,98 \mathrm{~km}^{2}$ dan 63 sel untuk wilayah sub-urban dengan luas sel masing-masing sel adalah $1,53 \mathrm{~km}^{2}$.
\end{abstract}

Kata kunci : Fixed WiMAX, Demand Site, Urban, Sub-urban, Base Station.

\section{Pendahuluan}

WiMAX adalah singkatan dari Worldwide Interoperability for Microwave Access, merupakan teknologi akses nirkabel pita lebar (broadband wireless access atau disingkat BWA) yang memiliki kecepatan akses yang tinggi dengan jangkauan yang luas, menerapkan QoS serta memiliki kemampuan Line of Sight (LOS) dan Non Line of Sight (NLOS). WiMAX merupakan evolusi dari teknologi BWA sebelumnya dengan fitur-fitur yang lebih menarik.

Disamping kecepatan data yang tinggi mampu diberikan, WiMAX juga merupakan teknologi dengan open standar. Dalam arti komunikasi perangkat WiMAX antara beberapa vendor yang berbeda tetap dapat dilakukan (tidak proprietary). Dengan kecepatan akses yang tinggi, WiMAX layak diaplikasikan untuk last mile broadband connections, backhaul, dan high speed enterprise.

Berdasarkan

mekanisme aksesnya, sistem WiMAX dibedakan atas fixed access, nomadic access, portability, simple mobility, dan full mobility.

Aplikasi yang dilakukan user senantiasa berkembang. Aplikasi yang ada tidak hanya dilakukan oleh user 
yang bersifat fixed, namun telah berkembang menjadi nomadic, bahkan mobile. Hal ini tentu hanya dapat dilakukan oleh teknologi yang didesain untuk dapat bekerja baik dalam lingkungan yang fixed, nomadic, maupun mobile. WiMAX didesain untuk dapat bekerja meng-cover berbagai kondisi user tersebut dengan tetap menjaga $Q o S$ bagi user.

\section{Metode Penelitian}

Bentuk penelitian yang akan digunakan dalam penelitian ini adalah kajian referensi; dengan mencari, mengumpulkan dan mempelajari berbagai referensi yang berkaitan dengan Teknologi WiMAX yang meliputi standar yang dikeluarkan oleh IEEE, spesifikasi perangkat, dan dokumen yang relevan serta melakukan beberapa asumsi asumsi sebagai data awal untuk merencanakan luas sel dan kebutuhan base station, perencanaan luas sel dan kebutuhann base station dilakukan dengan perumusan tahapan-tahapan yang diperlukan. Diawali dengan beberapa asumsi-asumsi sebagai data awal yang selanjutnya menjadi acuan untuk perhitungan matematis untuk menentukan jumlah sel, coverage, dan kebutuhan base station.

\section{Hasil dan Pembahasan}

Penelitian ini diawali dengan beberapa asumsi-asumsi antara lain jumlah populasi sebanyak 500.000 jiwa dengan luas wilayah $240 \mathrm{~km}^{2}$ yang terdiri dari $60 \%$ Urban dan $40 \%$ Suburban. Profil potensi pasar yang ada dari hasil survey adalah sebagai berikut; dari total populasi, $72 \%$ merupakan kriteria yang bisa dikatakan memiliki cukup umur dan $90 \%$ yang cukup potensial dari segi pendapatan untuk menjadi pelanggan WiMAX dan $80 \%$ yang memiliki ketertarikan terhadap layanan
WiMAX yang ditawarkan. Dari data competitor, pertumbuhan penetrasi pelanggan bisa mencapai $75 \%$ per tahun dengan strategi marketing yang tepat. Diproyeksikan trafik rata-rata gabungan voice dan data yang dihasilkan per user pada $\mathrm{BCH}$ (Busiest Call Hour) rata-rata $45 \mathrm{mEr} /$ user pada tahun awal, dan mengalami pertumbuhan rata-rata $12 \%$ per tahun.

Tahapan berikutnya setelah ditentukan beberapa asumsi-asumsi adalah persiapan mencakup keseluruhan pekerjaan meliputi pemilihan teknologi yaitu Fixed WiMAX dengan spesifikasi :
Frekuensi kerja $\quad: 2,3 \mathrm{GHz}$
Bandwidth layanan : $5 \mathrm{MHz}$
Kecepatan voice $\quad: 12,2 \mathrm{Kbps}$
Kecepatan data $\quad: 144 \mathrm{Kbps}$

Pemodelan propagasi : Stanford University Interm (SUI)

Dari asumsi-asumsi yang ditetapkan diperoleh data awal sebagai berikut :

a. Total populasi 500.000 jiwa

b. Luas wilayah $240 \mathrm{~km}^{2}$

c. Daerah Urban; $144 \mathrm{~km}^{2}$

d. Daerah Sub-urban; $96 \mathrm{~km}^{2}$

e. Addressable Market $=324.000$ jiwa

f. Potensial Demand of Population = 259.000 jiwa

g. Diasumsikan pada kondisi awal pasar yang dapat diraih hanya $10 \%$ dan akan mengalami pertumbuhan setiap tahunnya.

Potensial Demand pada tahun pertama adalah :

$\rightarrow 10 \% \quad$ X 259.000 jiwa $=25.920$ jiwa

h. Dari potensial demand pada tahun pertama diasumsikan $80 \%$ berada pada wilayah urban dan sisanya sebesar $20 \%$ berada pada wilayah sub-urban.

Wilayah Urban :

$\rightarrow 80 \%$ X $25.920=20.736$ jiwa

Wilayah Sub-urban : 
$\rightarrow 20 \%$ X $25.920=5.184$ jiwa

\section{Wilayah Urban}

\section{a. Perhitungan Estimasi Jumlah Pelanggan}

$$
P_{n}=P_{0}\left(1+f_{p}\right)^{n}
$$

Dimana,

$P_{0}=$ jumlah user saat perencanaan

$$
f_{p}=\text { faktor pertumbuhan }
$$

pelanggan

$$
n=\text { jumlah tahun prediksi }
$$

Dengan menggunakan persamaan (1) diperoleh data jumlah pelanggan pada tahun ke $n$ seperti pada Tabel 1 .

Tabel 1. Jumlah pelanggan tahun ke $\mathrm{n}$

\begin{tabular}{|c|c|c|}
\hline Tahun & $\begin{array}{c}\text { Pertumbuhan } \\
\text { Pelanggan }\end{array}$ & Jumlah Pelanggan \\
\hline 2010 & $20 \%$ & 20,736 \\
\hline 2011 & $20 \%$ & 24,883 \\
\hline 2012 & $30 \%$ & 35,044 \\
\hline 2013 & $45 \%$ & 63,216 \\
\hline 2014 & $50 \%$ & 104,976 \\
\hline 2015 & $50 \%$ & 157,464 \\
\hline
\end{tabular}

\section{b. Perhitungan Pelanggan}

Kepadatan

Untuk menentukan kepadatan pelanggan digunakan persamaan :

Kepadatan user $=$ jumla $h$ pelanggan luas wilaya $h \quad . .$.

Dengan menggunakan persamaan (2) diperoleh data kepadatan pelanggan pada tahun tahun ke $\mathrm{n}$ seperti pada Tabel 2.

Tabel 2. Kepadatan pelanggan.

\begin{tabular}{|c|c|c|c}
\hline Tahun & $\begin{array}{c}\text { Luas Wilayah } \\
\left(\mathrm{Km}^{2}\right)\end{array}$ & Jumlah Pelanggan & $\begin{array}{c}\text { Kepadatan } \\
\text { Pelanggan/Km }\end{array}$ \\
\hline 2010 & 144 & 20,736 & 144 \\
\hline 2011 & 144 & 24,883 & 173 \\
\hline 2012 & 144 & 35,044 & 243 \\
\hline 2013 & 144 & 63,216 & 439 \\
\hline 2014 & 144 & 104,976 & 729 \\
\hline 2015 & 144 & 157,464 & 1,094 \\
\hline
\end{tabular}

\section{a. Estimasi Kebutuhan Trafik :}

Layanan Voice: $50 \%$ dari total trafik (12,2 kbps)

Data: $50 \%$ dari total trafik (144 Kbps)

Trafik yang di-generate user sebesar $45 \mathrm{mE}$ dan mengalami pertumbuhan sebesar $12 \%$ tiap tahun. Data inilah yang digunakan untuk menghitung Busy Hour Call Attemp (BHCA) dengan persamaan :

$$
\begin{gathered}
\text { BHCA }= \\
\text { Trafik/user } \\
\hline \text { durasi panggilan }
\end{gathered}
$$

Asumsi rata-rata jumlah durasi panggilan untuk voice adalah 2 menit sedangkan untuk data adalah 20 menit sehingga diperoleh data $\mathrm{BHCA}$

Tabel 3. BHCA Voice dan Data

\begin{tabular}{|c|c|c|c|c|c|}
\hline Layanan & BCHA & Presentasi & Call durasi & BCH & Pertumbuhan \\
\hline Voice & 2.7 & $50 \%$ & 2 menit & $45 \mathrm{mErlang}$ & $12 \%$ \\
\hline Data & 0.27 & $50 \%$ & 20 menit & $45 \mathrm{mErlang}$ & $12 \%$ \\
\hline
\end{tabular}

\section{b. Perhitungan Offered Bit Quantity $(O B Q)$}

Perhitungan OBQ dapat dirumuskan pada persamaan di bawah ini

$$
O B Q=\frac{\sigma \times \rho \times c a l l \text { duration } \times B H C A \times B W}{3600}
$$

Dimana :

$\sigma \quad$ : kepadatan pelanggan potensial dalam suatu daerah (user $/ \mathrm{km}^{2}$ )

$\mathrm{p}$ : penetrasi pengguna tiap layanan

d : lama panggilan efektif [s]

BHCA : Busy Hour Call Attemp [call/s]

BW : bandwidth tiap layanan [Kbps]

Dengan menggunakan persamaan (4) diperoleh data OBQ voice dan data pada Tabel 4 dan Tabel 5. 
Tabel 4. Offered Bit Quantity untuk Voice

\begin{tabular}{|c|c|c|c|c|c|c|}
\hline Tahun & OBQ & $\begin{array}{c}\text { Kapadatan } \\
\text { Pelanggan (o) }\end{array}$ & Pentrasi $(\rho)$ & $\begin{array}{c}\text { Lama } \\
\text { Pangglan }\end{array}$ & BHCA & BW \\
\hline 2010 & 55.34 & 144 & 0.7 & 60 & 2.7 & 12.2 \\
\hline 2011 & 74.38 & 173 & 0.7 & 60 & 3.024 & 12.2 \\
\hline 2012 & 117.32 & 243 & 0.7 & 60 & 3.387 & 12.2 \\
\hline 2013 & 237 & 439 & 0.7 & 60 & 3.793 & 12.2 \\
\hline 2014 & 440.78 & 729 & 0.7 & 60 & 4.248 & 12.2 \\
\hline 2015 & 740.54 & 1,094 & 0.7 & 60 & 4.758 & 12.2 \\
\hline
\end{tabular}

Tabel 5. Offered Bit Quantity (OBQ) untuk Data

\begin{tabular}{|c|c|c|c|c|c|c|}
\hline Tahun & OBQ & $\begin{array}{c}\text { Kapadatan } \\
\text { Pelanggan (o) }\end{array}$ & Penetrasi $(\rho)$ & $\begin{array}{c}\text { Lama } \\
\text { Panggilan }\end{array}$ & $\mathrm{BHCA}$ & BW \\
\hline 2010 & 279.94 & 144 & 0.3 & 600 & 0.27 & 144 \\
\hline 2011 & 376.23 & 173 & 0.3 & 600 & 0.302 & 144 \\
\hline 2012 & 593.45 & 243 & 0.3 & 600 & 0.339 & 144 \\
\hline 2013 & $1,198.99$ & 439 & 0.3 & 600 & 0.379 & 144 \\
\hline 2014 & $2,229.95$ & 729 & 0.3 & 600 & 0.425 & 144 \\
\hline 2015 & $3,344.93$ & 1,094 & 0.3 & 600 & 0.425 & 144 \\
\hline
\end{tabular}

Tabel 6. Rata-rata Offered Bit Quantity (OBQ) Voice dan Data

\begin{tabular}{|c|c|c|c|c|c|c|}
\hline \multirow{2}{*}{ Layanan } & \multicolumn{6}{|c|}{$\sum \mathrm{OBQ}\left(\mathrm{Kbpskm}^{2}\right)$ tahun ke n } \\
\cline { 2 - 7 } & 0 & 1 & 2 & 3 & 4 & 5 \\
\hline Voice & 55.34 & 74.38 & 117.32 & 237 & 440.78 & 740.54 \\
\hline Data & 279.94 & 376.23 & 593.45 & $1,198.99$ & $2,229.95$ & $3,344.93$ \\
\hline Rata-rata OBQ & 167.64 & 225.3 & 355.38 & 718 & $1,3355.37$ & $2,042.74$ \\
\hline
\end{tabular}

\section{c. Perhitungan Luas Cakupan Sel}

Luas cakupan satu sel

$$
=\frac{\text { Kapasitas informasi tiap sel }}{\text { Offered bit quantity }(O B Q)}
$$

Dengan menggunakan persamaan (5) diperoleh data luas cakupan sel pada Tabel 7.

Tabel 7. Luas cakupan sel.

\begin{tabular}{|c|c|c|c|}
\hline Tahun & $\begin{array}{c}\text { Luas Cakupan } \\
\text { Sel(Km2) }\end{array}$ & $\begin{array}{c}\text { Kapasitas } \\
\text { Informasi tiap sel }\end{array}$ & OBQ \\
\hline 2010 & 11.93 & 2000 & 167.64 \\
\hline 2011 & 8.88 & 2000 & 225.3 \\
\hline 2012 & 5.63 & 2000 & 355.38 \\
\hline 2013 & 2.79 & 2000 & 718 \\
\hline 2014 & 1.5 & 2000 & $1,335.37$ \\
\hline 2015 & 0.98 & 2000 & $2,042.74$ \\
\hline
\end{tabular}

\section{d. Perhitungan Jumlah Sel}

Jumlah sel yang diperlukan dapat dihitung dengan menggunakan persamaan berikut:

Jumlah sel

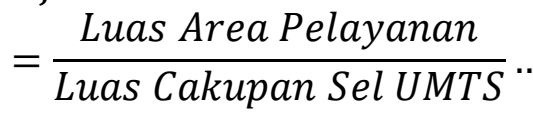

Dengan menggunakan persamaan (6) diperoleh data jumlah sel pada Tabel 8 .

Tabel 8. Jumlah sel

\begin{tabular}{|c|c|c|c|}
\hline Tahun & $\begin{array}{c}\text { Jumlah Sel } \\
(\mathrm{Km} 2)\end{array}$ & $\begin{array}{c}\text { Luas area urban } \\
(\mathrm{Km} 2)\end{array}$ & $\begin{array}{c}\text { Luas cakupan } \\
\text { satu sel (Km2) }\end{array}$ \\
\hline 2010 & 12 & 144 & 11.93 \\
\hline 2011 & 16 & 144 & 8.88 \\
\hline 2012 & 26 & 144 & 5.63 \\
\hline 2013 & 52 & 144 & 2.79 \\
\hline 2014 & 96 & 144 & 1.5 \\
\hline 2015 & 147 & 144 & 0.98 \\
\hline
\end{tabular}

\section{e. Perhitungan Radius Sel}

Luas dari cakupan sel yang diinginkan berbentuk hexagonal ditentukan dengan persamaan di bawah ini :

$$
\begin{aligned}
\text { Luas Sel } & =2,6 \times r^{2} \ldots \ldots \ldots(7) \\
R & =\sqrt{\frac{\text { Luas sel }}{2,6}}, \mathrm{r}=\text { radius sel }
\end{aligned}
$$

Dengan menggunakan persamaan 7 diperoleh data radius sel pada Table 9

Tabel 9. Radius sel

\begin{tabular}{|c|c|c|}
\hline Tahun & Radius Sel $(\mathrm{Km})$ & Luas Sel $(\mathrm{Km} 2)$ \\
\hline 2010 & 2.14 & 11.93 \\
\hline 2011 & 1.85 & 8.88 \\
\hline 2012 & 1.47 & 5.63 \\
\hline 2013 & 1.04 & 2.79 \\
\hline 2014 & 0.76 & 1.5 \\
\hline 2015 & 0.61 & 0.98 \\
\hline
\end{tabular}

\section{Wilayah Sub-urban}

Data pada wilayah sub-urban dapat ditentukan dengan memnggunakan persamaan (1) s/d persamaan (7). 
Tabel 10. Jumlah pelanggan tahun ke $\mathrm{n}$

\begin{tabular}{|c|c|c|}
\hline Tahun & $\begin{array}{c}\text { Pertumbuhan } \\
\text { Pelanggan }\end{array}$ & Jumlah Pelanggan \\
\hline 2010 & $20 \%$ & 5,184 \\
\hline 2011 & $20 \%$ & 6,221 \\
\hline 2012 & $30 \%$ & 8,761 \\
\hline 2013 & $45 \%$ & 15,804 \\
\hline 2014 & $50 \%$ & 26,244 \\
\hline 2015 & $50 \%$ & 39,366 \\
\hline
\end{tabular}

Tabel 11. Kepadatan pelanggan.

\begin{tabular}{|c|c|c|c|}
\hline Tahun & $\begin{array}{c}\text { Luas Wilayah } \\
\left(\mathrm{Km}^{2}\right)\end{array}$ & $\begin{array}{c}\text { Jumlah } \\
\text { Pelanggan }\end{array}$ & $\begin{array}{c}\text { Kepadatan } \\
\text { User/Km }\end{array}$ \\
\hline 2010 & 96 & 5,184 & 54 \\
\hline 2011 & 96 & 6,221 & 65 \\
\hline 2012 & 96 & 8,761 & 91 \\
\hline 2013 & 96 & 15,804 & 165 \\
\hline 2014 & 96 & 26,244 & 273 \\
\hline 2015 & 96 & 39,366 & 410 \\
\hline
\end{tabular}

Tabel 12. BHCA Voice dan Data

\begin{tabular}{|c|c|c|r|c|c|}
\hline Layanan & BCHA & $\begin{array}{c}\text { Presentaasi } \\
\text { Layanan }\end{array}$ & Calldurasi & BCH & $\begin{array}{c}\text { Pertumbulan } \\
\text { BCH }\end{array}$ \\
\hline Voice & 1.929 & $70 \%$ & 2 menit & $45 \mathrm{mErlang}$ & $12 \%$ \\
\hline Data & 0.45 & $30 \%$ & 20 ment & $45 \mathrm{mErlang}$ & $12 \%$ \\
\hline
\end{tabular}

Tabel 13. Offered Bit Quantity (OBQ) untuk Voice

\begin{tabular}{|c|c|c|c|c|c|c|}
\hline Tahun & OBQ & $\begin{array}{c}\text { Kapadatan } \\
\text { Pelangagn( }(0)\end{array}$ & Penetrasi( $)$ & Call duration & BHCA & BW \\
\hline 2010 & 55.34 & 144 & 0.7 & 60 & 2.7 & 12.2 \\
\hline 2011 & 74.38 & 173 & 0.7 & 60 & 3.024 & 12.2 \\
\hline 2012 & 117.32 & 243 & 0.7 & 60 & 3.387 & 12.2 \\
\hline 2013 & 237 & 439 & 0.7 & 60 & 3.793 & 12.2 \\
\hline 2014 & 440.78 & 729 & 0.7 & 60 & 4.248 & 12.2 \\
\hline 2015 & 740.54 & 1,094 & 0.7 & 60 & 4.758 & 12.2 \\
\hline
\end{tabular}

Tabel 14. Offered Bit Quantity (OBQ) untuk Data

\begin{tabular}{|c|c|c|c|c|c|c|}
\hline Tahun & OBQ & $\begin{array}{c}\text { Kapadatan } \\
\text { Pelangogan(()) }\end{array}$ & Pentertai( ()) & Call duration & BHCA & BW \\
\hline 2010 & 279.94 & 144 & 0.3 & 600 & 0.27 & 144 \\
\hline 2011 & 376.23 & 173 & 0.3 & 600 & 0.302 & 144 \\
\hline 2012 & 593.45 & 243 & 0.3 & 600 & 0.339 & 144 \\
\hline 2013 & $1,198.99$ & 439 & 0.3 & 600 & 0.379 & 144 \\
\hline 2014 & $2,229.95$ & 729 & 0.3 & 600 & 0.425 & 144 \\
\hline 2015 & $3,344.93$ & 1,094 & 0.3 & 600 & 0.425 & 144 \\
\hline
\end{tabular}

Tabel 15. Rata-rata Offered Bit Quantity (OBQ) Voice dan Data

\begin{tabular}{|c|c|c|c|c|c|c|}
\hline \multirow{2}{*}{ Layanan } & \multicolumn{7}{|c|}{$\sum \mathrm{OBO}\left(\mathrm{Kbps}_{\mathrm{k}} \mathrm{km}^{2}\right)$ tahum ke n } \\
\cline { 2 - 7 } & 0 & 1 & 2 & 3 & 4 & 5 \\
\hline Voice & 14.82 & 27.89 & 43.99 & 88.88 & 165.29 & 277.7 \\
\hline Data & 174.96 & 235.15 & 370.9 & 749.37 & $1,393.72$ & $2,341.45$ \\
\hline Rata-rata OBQ & 94.89 & 131.52 & 207.45 & 419.12 & 779.51 & $1,309.58$ \\
\hline
\end{tabular}

Tabel 16. Luas cakupan sel.

\begin{tabular}{|c|c|c|c|}
\hline Tahun & $\begin{array}{c}\text { Luas Cakupan Sel } \\
(\mathrm{Km} 2)\end{array}$ & $\begin{array}{c}\text { Kapasitas } \\
\text { Informasi tiap sel }\end{array}$ & OBQ \\
\hline 2010 & 21.08 & 2000 & 94.89 \\
\hline 2011 & 15.21 & 2000 & 131.52 \\
\hline 2012 & 9.64 & 2000 & 207.45 \\
\hline 2013 & 4.77 & 2000 & 419.12 \\
\hline 2014 & 2.57 & 2000 & 779.51 \\
\hline 2015 & 1.53 & 2000 & $1,309.58$ \\
\hline
\end{tabular}

Tabel 17. Jumlah sel

\begin{tabular}{|c|c|c|c|}
\hline Tahun & Jumlah Sel & $\begin{array}{c}\text { Luas wilayah } \\
\text { suburban (Km2) }\end{array}$ & $\begin{array}{c}\text { Luas cakupan satu } \\
\text { sel (Km2) }\end{array}$ \\
\hline 2010 & 5 & 96 & 21.08 \\
\hline 2011 & 6 & 96 & 15.21 \\
\hline 2012 & 10 & 96 & 9.64 \\
\hline 2013 & 20 & 96 & 4.77 \\
\hline 2014 & 37 & 96 & 2.57 \\
\hline 2015 & 63 & 96 & 1.53 \\
\hline
\end{tabular}

Tabel 18. Radius sel

\begin{tabular}{|c|c|c|}
\hline Tahun & Radius sel $(\mathrm{km})$ & Luas sel $(\mathrm{km})$ \\
\hline 2010 & 2.85 & 21.08 \\
\hline 2011 & 2.42 & 15.21 \\
\hline 2012 & 1.93 & 9.64 \\
\hline 2013 & 1.35 & 4.77 \\
\hline 2014 & 0.99 & 2.57 \\
\hline 2015 & 0.77 & 1.53 \\
\hline
\end{tabular}

Tabel 19. Radius sel, jumlah sel, dan luas sel wilayan urban dan sub-urban

\begin{tabular}{|c|c|c|c|c|c|c|}
\hline \multirow{2}{*}{ Tahun } & \multicolumn{3}{|c|}{ Urban } & \multicolumn{3}{c|}{ Sub-urban } \\
\cline { 2 - 7 } & Raduus sel (km) & Jumlah sel & Luas sel $(\mathrm{km})$ & Radius sel (km) & Jumlah sel & Llas sel $(\mathrm{km})$ \\
\hline 2010 & 2.14 & 12.07 & 11.93 & 2.85 & 4.55 & 21.08 \\
\hline 2011 & 1.85 & 16.22 & 8.88 & 2.42 & 6.31 & 15.21 \\
\hline 2012 & 1.47 & 25.59 & 5.63 & 1.93 & 9.96 & 9.64 \\
\hline 2013 & 1.04 & 51.7 & 2.79 & 1.35 & 20.12 & 4.77 \\
\hline 2014 & 0.76 & 96.15 & 1.5 & 0.99 & 37.42 & 2.57 \\
\hline 2015 & 0.61 & 147.08 & 0.98 & 0.77 & 62.86 & 1.53 \\
\hline
\end{tabular}




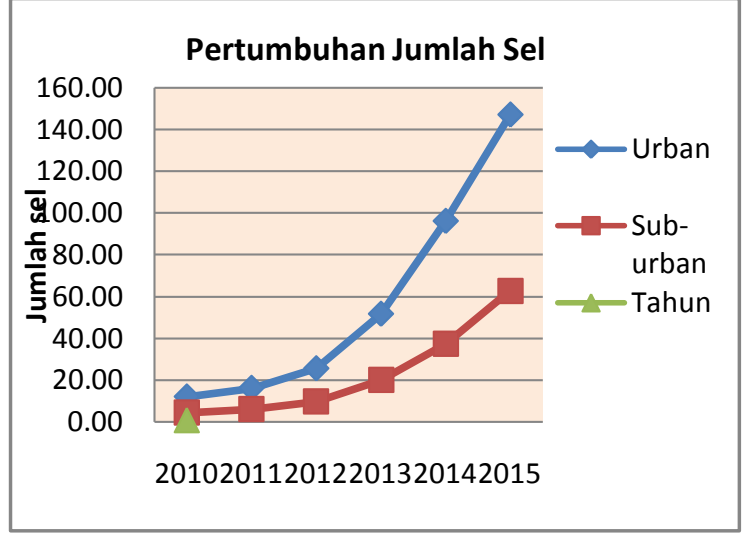

Pertumbuhan jumlah pelanggan untuk wilayah urban dan sub-urban

Dari grafik diatas dapat dilihat bahwa jumlah sel akan terus bertambah sesuai pertambahan jumlah pelanggan dan peningkatan trafik yang di-generate oleh user. Jika pelanggan dan trafik meningkat maka kapasitas sel akan meningkat sehingga wilayah cakupan sel akan semakin berkurang.

Berdasarkan perhitungan demand side terdapat perbedaan radius jangkauan layanan. Pada perancangan ini akan dipilih hasil rancangan berdasarkan demand side tahun ke-5, hal ini dikarenakan agar seluruh user dipastikan dapat terlayani. Karena apabila dilihat dari sisi pelanggan akan diketahui seberapa besar kebutuhannya sehingga perancangan akan lebih efektif dan kemungkinan terjadinya blocking akan lebih kecil.

\section{Kesimpulan}

Berdasarkan perhitungan dan analisa data yang dilakukan maka pada penelitian ini dapat disimpulkan :

1. Pertumbuhan kebutuhan jumlah sel setiap tahun mengalami peningkatan sebanding dengan peningkatan jumlah pelanggan.
2. Untuk layanan voice dan data pada tahun 2015 diperlukan jumlah sel sebanyak 148 sel untuk wilayah urban dengan luas masing-masing sel adalah $0,98 \mathrm{~km}^{2}$ dan 63 sel untuk wilayah suburban dengan luas sel masing-masing sel adalah $1,53 \mathrm{~km}^{2}$.

\section{Saran}

Diperlukan adanya penelitian lebih lanjut mengenai perencanaan jumlah base station berdasarkan power link budget sebagai perbandingan untuk menentukan kebutuhan jumlah base station.

\section{Daftar Pustaka}

IEEE standard for Local and metropolitan area networks. "Part 16 : Air Interface for Broadband Wireless Access Systems"

Jeffrey G. Andrews., Arunabha Ghosh., Rias Muhamed. "Fundamentals of WiMAX Understanding Broadband Wireless Networking"

T.S. $\quad$ Rappaport. Wireless Communication : Principles and Practice" Second Edition. Prentice Hall. 2002.

WiMAX Forum. Fixed, Nomadic, Portable and Mobile Applications for 802.16-2004 and 802.16e WiMAX Networks, November 2005.

Zerihun Abate. "WiMAX RF Systems Engineering",Artech 